\title{
Aplikasi Teknologi Augmented Reality dalam Meningkatkan Kuantitas Konten Caption display Koleksi Artefak Etnografi Museum Panji
}

\author{
Jonathan Pramana ${ }^{1}$, Erandaru², Deny Tri Ardianto ${ }^{3}$ \\ 1,2Program Studi Desain Komunikasi Visual, Fakultas Seni \& Desain, Universitas Kristen Petra \\ Jl. Siwalankerto 121-131, Surabaya, 60236 \\ ${ }^{3}$ Program Studi Desain Komunikasi Visual, Fakultas Seni Rupa \& Desain, Universitas Negeri Sebelas Maret \\ Jl. Ir. Sutami No. 36A, Surakarta, 57126

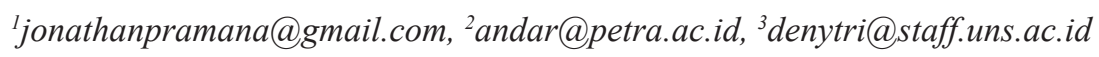

Museum masa kini memiliki salah satu fungsi sebagai sumber pengetahuan yang relevan dengan artefak yang ditampilkan. Caption yang menyertai artefak merupakan salah satu media yang sering digunakan museum dalam memenuhi fungsi tersebut, tetapi karakter fisik dari caption menjadi keterbatasan dalam mengkomunikasikan materi secara lebih terinci dan kurang mampu membentuk relasi interaktif dengan pengunjung, sehingga informasi yang ditampilkan kurang berfungsi optimal sebagai pengetahuan. Teknologi Augmented reality (AR) memungkinkan tersajinya konten multimedia melalui berbagai modalitas komunikasi dan meningkatkan kuantitas dan kualitas informasi. Tetapi di sisi yang lain, aplikasi teknologi ini juga membutuhkan teknis pendekatan komunikasi yang berbeda dibanding media cetak. Karakter teknologi ini memungkinkan hadirnya interaksi yang dapat digunakan sebagai strategi gamifikasi sebagai usaha untuk membangun kedekatan emosional dan relevansi antara pengunjung dan artefak, sehingga informasi yang disajikan dapat bermanfaat sebagai sumber pengetahuan bagi pengunjung. Artikel ini memaparkan permasalahan caption display pada artefak koleksi etnografi Museum Panji berdasar temuan penelitian dengan metode deskriptif, serta menawarkan pendekatan solusi permasalahan melalui integrasi teknologi augmented reality.

Kata Kunci: augmented reality, museum captions, media interaktif

\section{Application of Augmented Reality Technology in Augmenting Caption Display Content for the Ethnographic Artefacts Collection at Panji Museum}

Modern museum should provide audiences with knowledge relevant with artefacts displayed. Captions has generally been used as media to display artefacts' information, however the limitation of printed space available, modality and the constraint of time and distance between audiences and caption's placard has been a restriction factor in creating engagement necessary for translating information into knowledge. Augmented reality (AR) provides the means to display rich media content accessible to audiences, enabling the use of multimodal communication and providing more information in terms of quantity and quality. In the other hand, AR requires a different approach (compared to traditional printed media) in conveying messages to enable the translation of information into knowledge. The use of interactivity and gamification in augmented captions provides the required emotional engagement for bridging relevance between audiences and the displayed information, gaining knowledge in the process. This article analyzes problems in the use of caption display for ethnographic artefacts collection at Panji Museum through descriptive research method and proposing approach through an integrated use of augmented reality technology.

Keywords: augmented reality, museum captions, interactive media

Proses Review : 1 - 20 Mei 2021, Dinyatakan Lolos: 31 Mei 2021 


\section{PENDAHULUAN}

Museum Panji Malang adalah sebuah museum yang didirikan pada tahun 2016 dan dikelola secara mandiri oleh Dwi Cahyono di Desa Slamet, Kecamatan Tumpang, Kabupaten Malang. Museum ini diberi nama Panji untuk mendukung budaya Panji sebagai salah satu budaya asli yang berasal dari Jawa. Artefak yang ditampilkan dalam museum ini beragam mulai dari koleksi berbagai jenis wayang (wayang beber, wayang blawong, wayang krucil, wayang purwa, wayang tengger, dan masih banyak koleksi wayang lainnya), koleksi benda-benda peninggalan kerajaan-kerajaan di Jawa, koleksi spesimen palaeontology (fosil), sampai dengan artefak masa lalu di Indonesia.

Selain sebagai tempat untuk menyimpan dan menjaga keamanan koleksi benda sejarah, museum ini juga bertujuan sebagai prasarana pembelajaran sejarah dan untuk melestarikan keberadaan sejarah budaya lokal pada masyarakat (Akaibara, 2017). Salah satu strategi pengelola dalam mewujudkan fungsi tersebut adalah dengan menyasar anak-anak usia sekolah sampai dengan dewasa muda sebagai sasaran utama pengunjung museum. Pengemasan tampilan museum dan informasi yang disajikan harus sebisa mungkin menarik, mudah dipahami dan memiliki relevansi dengan sasaran yang dituju.

Observasi terhadap teknis penyajian informasi dalam caption koleksi artefak Museum Panji yang dilakukan pada bulan November 2017, mendapatkan sebagian besar caption berwujud deskripsi secara panjang lebar tanpa mempertimbangkan kemudahan baca dan belum dilengkapi dengan naratif relefansinya dengan sejarah asal masanya. Menurut sejumlah pengunjung, beberapa paparan caption display dirasa terlalu panjang dan kurang menarik untuk dibaca. Kurang maksimalnya caption display koleksi menyebabkan museum masih belum dapat memenuhi tujuan pendiri dalam melestarikan kembali sejarah budaya lokal pada masyarakat.

Teknologi augmented reality sudah cukup lama dan sering digunakan. Penggunaan teknologi ini didasari oleh kemajuan digital teknologi dan dapat membantu dalam bidang media komunikasi dalam memperkaya informasi. Teknologi ini digunakan untuk meningkatkan kuantitas informasi yang ditampilkan karena memiliki kemampuan mengkombinasikan gambar nyata maupun virtual, real time, dan dapat membaca objek 3D (Hollerer \& Schmalstieg, 2016). Teknologi ini memungkinkan penggabungan informasi visual yang dihasilkan teknologi cetak tradisional dengan informasi visual yang dihasilkan teknologi digital melalui tampilan layar. Karakteristik teknologi tersebut memiliki potensi sebagai media bantu dalam meningkatkan kuantitas konten caption display koleksi aretefak museum. Artikel ini membahas proses perancangan dan pengamatan terhadap aplikasi teknologi augmented reality dalam caption display koleksi artefak etnografi di Museum Panji.

\section{METODE PENELITIAN PERANCANGAN}

Metode penelitian untuk perancangan ini merupakan penelitian deskriptif dengan tujuan untuk mengidentifikasi permasalahan caption display yang digunakan dalam penyajian artefak ruang koleksi etnografi melalui analisa terhadap hasil pengamatan lapangan dan membandingkannya dengan tinjaun pustaka serta fungsi yang diharapkan sebagaimana wawancara dengan pihak pengelola museum. Analisa tinjaun pustaka terkait teknologi augmented reality diperlukan untuk memetakan keunggulan yang dimungkinkan untuk diintegrasikan dengan caption display cetak.

\section{TINJAUAN PUSTAKA}

\section{Caption display Museum}

Caption display adalah label penjelas koleksi yang berisi perpaduan antara kata - kata menarik, kalimat pendek, dan ungkapan kreatif. Sedikitnya pengunjung yang membaca setiap kata di label museum, maka tujuan dari setiap label adalah menarik mereka untuk membaca kata sebanyak mungkin. Label terlalu panjang dapat membuat pembaca enggan untuk membaca, sedangkan yang diperlukan adalah penjelasan yang sesingkat dan semudah mungkin untuk dipahami (Kenney, 2008).

Label dapat digolongkan menjadi tiga macam (Kenney, 2008), yaitu:

\section{Label Pengantar}

Label ini menjadi label pertama yang di lihat pengunjung saat memasuki ruangan dan mendorong pengunjung untuk melihat keseluruhan isi galerinya. Label ini juga bisa berfungsi untuk menjelaskan pengantar topik, mengapa penting untuk dipelajari, namun tetap terjaga agar tidak terlalu detail.

\section{Label Bagian}

Label Bagian merupakan label pengantar mini yang bertujuan untuk menjelaskan setiap sub topik yang ada. Panjang dari label ini setidaknya sekitar 100 sampai 200 kata. Jika label terlalu panjang, maka sebaiknya memecahnya menjadi label yang terpisah sehingga dapat mengurangi kelelahan mata pembaca.

\section{Label Objek}

Label Objek adalah label terpendek dari semua label yang bertujuan untuk menggambarkan artefak dan gambar individual dari objek. Umumnya label objek terdiri dari 25 sampai 50 kata deskripsi. Isi dari label objek dapat ditambahkan dengan informasi yang dikumpulkan dan didukung dengan penelitian tambahan.

Caption display juga perlu memperhatikan aspek 
ergonomi huruf, dimana salah satu faktor yang membantu kemudahan baca caption display adalah ukuran huruf. Semakin jauh jarak baca caption display semakin besar pula ukuran huruf yang sebaiknya digunakan.

\section{Teknologi Augmented reality}

Augmented reality adalah teknologi yang memungkinkan sajian tampilan dunia nyata yang, baik secara langsung maupun tidak langsung, telah ditingkatkan kualitas informasi yang disampaikan melalui penambahan informasi hasil olahan komputer (Carmigniani, Furht, 2011:3). Silvia, Oliveira, dan Giraldi (2013) menuliskan dalam merancang augmented reality memiliki tiga aspek penting yaitu: (1) Kombinasi dari dunia nyata dengan dunia maya; (2) Interaktivitas terjadi secara real time; (3) Pendaftaran bentuk dalam 3D.

Komponen augmented reality terdiri dari scene generator, tracking system, dan display. Scene generator adalah sebuah perangkat atau software yang bertanggung jawab terhadap proses render scene. Tracking system adalah yang terpenting dalam penggunaan augmented reality, berfungsi sebagai membaca dan menyusun data objek antara dunia nyata dengan dunia maya sehingga dapat menyatu. Sedangkan dari segi display masih menjadi penghambat perkembangan sistem augmented reality karena memiliki keterbatasan dalam tampilannya (Silvia, Oliveira, Giraldi, 2003).

\section{Wawancara dan Pengamatan Lapangan}

Berdasar wawancara pada tanggal 9 Februari 2018 dengan Bapak Dwi Cahyono selaku pendiri Museum Panji, keinginan untuk mendirikan museum tersebut didasari atas keprihatinan terhadap fakta budaya seni tradisi daerahdaerah di Indonesia yang kurang mendapat perhatian dari bangsa sendiri, sedangkan di negara lain justru masih mengajarkan seni budaya yang berasal dari Indonesia dalam kurikulum sekolah. Salah satu budaya lisan yang berasal dari wilayah geografis Indonesia adalah Budaya Panji. Berdasar penelitian sejarah, budaya tersebut diyakini muncul dan berkembang di Jawa dan seiring luasnya wilayah kekuasaan dan pengaruh kerajaan-kerajaan di wilayah Nusantara, turut menyebar ke berbagai wilayah di luar Nusantara dan turut berpengaruh terhadap budaya tradisi di beberapa negara anggota ASEAN.

Museum Panji merupakan salah satu perwujudan dari visi Bapak Dwi Cahyono untuk berusaha memperkenalkan kembali sejarah dan budaya tradisi masa lalu kepada generasi muda masa kini melalui pendekatan living museum, khususnya untuk bagian koleksi alat peninggalan budaya manusia. Melalui tampilan visual suasana masa lalu dan dengan menghadirkan artefak dari masa lalu yang dapat dicoba dan dialami langsung oleh pengunjung, pendekatan tersebut diharapkan dapat menghadirkan interaksi antara pengunjung dengan visual dan artefak sebagai representasi sejarah dan budaya dari masa lalu, yang pada akhirnya diharapkan dapat memberikan tidak hanya pengetahuan, tetapi juga pemahaman dan keterikatan emosional dengan budaya dan sejarah masa lalu tersebut sebagai bagian dari jati diri bangsa.

Tinjauan fakta lapangan didapat melalui observasi yang dilakukan pada bulan November 2017 dan bulan Maret 2018. Keadaan Museum Panji Malang pada bulan Maret 2018 adalah dalam tahap renovasi untuk penataan ruangan. Renovasi menyebabkan beberapa barang dipindah lokasikan serta masih belum dapat tertata secara rapi. Beberapa koleksi dari Museum Panji merupakan koleksi pindahan dari Museum Tempoe Doeloe Malang.

Penggunaan caption display dalam Museum Panji berfungsi sebagai media untuk memberikan keterangan koleksi yang ditampilkan, yaitu memberikan keterangan nama artefak, asal artefak, tahun dan cara penggunaan artefak tersebut. Caption display pada beberapa artefak koleksi etnografi menggunakan struktur hirarki, typeface dan wujud fisik tampilan yang sama. Tiap caption display terdiri atas 2 bagian secara hirarki, yaitu bagian heading yang memuat nama artefak diletakkan paling atas dan bodycopy yang memuat keterangan terkait tahun, asal daerah dan cara penggunaan artefak terletak di bawahnya. Format peletakkan kalimat untuk heading adalah rata tengah, sedangkan bodycopy menggunakan rata kiri dan kanan (justify). Keduanya menggunakan jenis typeface dan ukuran yang sama, pembeda hanya pada tingkat ketebalan huruf, dimana heading dicetak menggunakan huruf tebal sedangkan bodycopy menggunakan ketebalan standar. Caption dicetak pada potongan kertas putih dan diselipkan diantara dua lapisan polikarbonat (mika tebal) bening. Caption display diletakkan menempel pada sisi depan atau samping artefak dengan ketinggian yang bervariasi tergantung dengan ketinggian bidang pada artefak yang memungkinkan luasan yang cukup untuk meletakkan caption display tersebut.

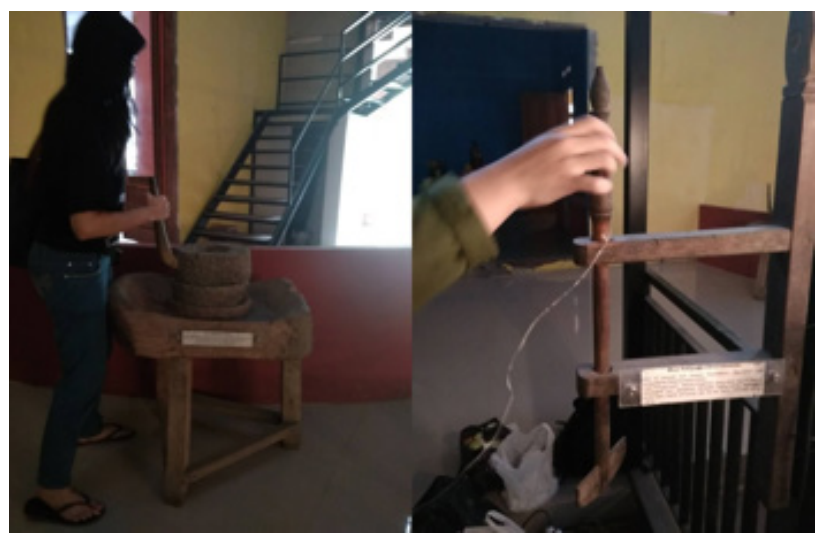

Gambar 1. Lokasi penempatan caption pada sisi bawah artefak (Sumber: pribadi, 2018) 


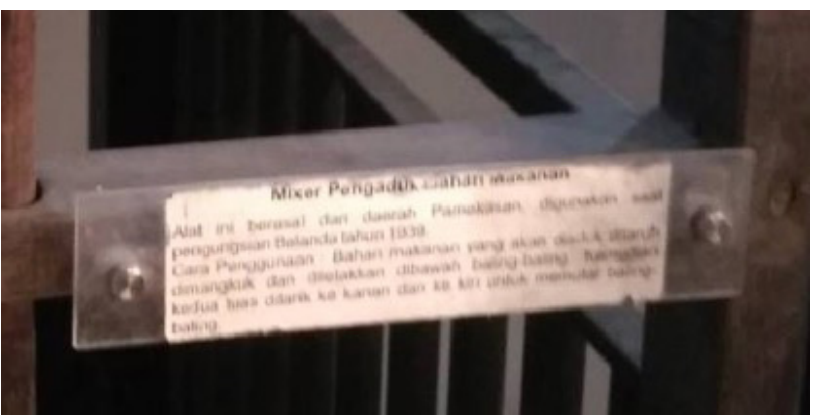

Gambar 2. Layout dan dimensi huruf pada caption

\section{Analisa}

Caption display adalah media pertama yang akan dilihat pengunjung saat mereka mengamati koleksi museum. Keunggulan dari media caption adalah media pertama sebagai penjelas koleksi, sehingga kebingungan dan rasa ingin tahu dari pengunjung akan dimainkan oleh media ini. Media awal ini adalah media yang paling penting, saat caption display menarik dan memberikan fakta yang menggelitik rasa keingintahuan pengunjung maka akan lebih mudah bagi pengunjung untuk mengenal koleksi dan cerita dibaliknya. Target memiliki psikologi pemikiran rasa ingin tahu yang tinggi harus terpikat terlebih dahulu dengan media ini kemudian diarahkan ke media lainnya.

Caption display berfungsi untuk mendapatkan perhatian dan rasa ingin tahu dari pengunjung yang nantinya pengunjung akan diarahkan ke media lain. Dengan adanya media ini, anak dapat mengerti apa koleksi museum itu, klasifikasi koleksinya, dan kegunaannya.

Analisa terhadap data hasil pengamatan caption display di koleksi artefak etnografi Museum Panji pada tanggal sebagaimana tersebut di sub-bab sebelumnya, menunjukkan bahwa berdasar fungsi dan jumlah kata yang terdapat pada caption display tersebut, bisa digolongkan sebagai label obyek. Tata letak huruf dalam bidang juga telah memperhatikan aspek ergonomis, khususnya dengan penerapan grid dan hirarki. Tetapi dari sisi peletakan caption display dirasa kurang sesuai karena posisi ketinggian terlalu rendah baik untuk pengunjung usia sekolah dasar dan bahkan dewasa. Sedangkan arah caption display yang menghadap ke samping maupun depan juga dirasa mengurangi tingkat kemudahan dan kenyamanan baca. Selain itu ukuran huruf dirasa masih terlalu kecil untuk sebuah caption display yang harus dapat dibaca dari jarak ideal 1-2 meter. Kualitas media cetak label juga kurang baik, tepian kertas tidak dipotong dengan rapi, warna kertas juga mulai menguning. Polikarbonat sebagai pelindung kertas pada beberapa bagian juga sudah terlihat buram, sehingga mengurangi keterbacaan huruf.

Analisa terhadap sisi pesan tersurat sudah cukup jelas terkait identitas artefak, asal dan tahun penggunaan. Tetapi deskripsi dari cara penggunaan artefak masih dirasa rancu karena berusaha memberikan arahan menggunakan kata dan kalimat dibandingkan kombinasi antara gambar dan kalimat. Beberapa artefak juga dirasa akan terbantukan dengan deskripsi yang lebih panjang dari batas 25-50 kata, yang sayangnya pada beberapa koleksi lainnya dalam museum yang sama, penerapan hal tersebut justru berdampak pada menurunnya kemudahan dan kenyamanan membaca.

\section{Simpulan Penelitian}

Museum Panji Malang belum sepenuhnya memiliki caption display penjelas koleksi yang ideal sebagaimana paparan tinjauan pustaka karena berbagai faktor sebagaimana yang telah dipaparkan dalam analisa. Hal tersebut dapat menganggu efektifitas fungsinya sebagai media pendukung untuk menyajikan koleksi artefak sebagaimana pendekatan yang diharapkan oleh pendiri museum.

Teknologi augmented reality sebagaimana telah dipaparkan dalam tinjaun pustaka, memiliki karakteristik yang memungkinkan untuk membantu mengatasi kekurangan yang terdapat di caption display. Keterbatasan caption display cetak untuk menampilkan konten dapat teratasi dengan hadirnya layar sebagai bagian dari media berbasis teknologi ini yang dapat menampilkan konten dalam berbagai wujud (multimedia) dan jumlah yang nyaris tak terbatas serta memungkinkan interaksi antara pengunjung dengan konten. Hal tersebut memudahkan pemahaman dan penyampaian kuantitas konten terkait artefak kepada pembaca. Konten yang ditampilkan juga dapat dibaca dengan lebih nyaman karena bidang tampilan bersifat lebih personal, yaitu dalam bentuk layar smartphone yang dioperasikan secara mandiri oleh masing-masing pengunjung. Konten dalam kondisi selalu terbarukan sesuai dengan informasi terbaru terkait artefak tersebut, dan tingkat kedalaman paparan serta bentuk komunikasi materi paparan dapat disesuaikan sesuai tingkatan usia dan minat melalui pengenalan terhadap profil pemilik layar tampilan.

Aplikasi teknologi augmented reality untuk meningkatkan kualitas fungsi display caption akan menghadirkan permasalahan dari sisi bagaimana teknis penerapannya. Pemahaman terkait keunggulan dna kekurangan masingmasing (caption display cetak dan media berbasis teknologi augmented reality) diharapkan dapat menjadi panduan awal untuk menghadirkan kolaborasi yang efektif dan efesien untuk menjawab tuntutan fungsi caption display sebagai media pendukung penyajian koleksi artefak etnografi melalui pendekatan living museum di Museum Panji.

\section{HASIL DAN PEMBAHASAN}

\section{Konsep Media}

Aplikasi teknologi augemented reality pada desain caption display bertujuan agar pengunjung museum dengan nyaman dapat melihat, membaca, serta memahami 
deskripsi koleksi. Penyajian konten caption display dilakukan secara penggabungan antar konten yang tercetak dan konten yang ditampilkan melalui media layar dengan menggunakan teknologi augmented reality. Deskripsi koleksi yang terlalu banyak dapat dipecah dan dimasukkan ke dalam media augmented reality untuk dihadirkan secara multimedia supaya mudah dan nyaman dipahami. Pengalaman interaksi pengunjung dengan konten juga dapat diperkaya dengan menghadirkan sisi permainan dalam menyajikan konten, yang memungkinkan untuk meningkatkan minat dan retensi pengetahuan terkait artefak, khususnya bagi pengunjung usia anak-anak dan remaja.

Sistem kerja kolaboratif antara caption display cetak dengan tampilan layar media augmented reality dimungkinkan dengan pembuatan sebuah aplikasi mobile yang dapat dijalankan dalam smartphone masing-masing pengunjung. Aplikasi tersebut akan menampilkan konten yang relevan dengan artefak melalui proses membaca penanda yang terdapat di caption display cetak melalui kamera.

\section{Alur Operasional Antarmuka Media}

Garis besar aplikasi dimulai dengan tampilan awal Main Menu. User dapat memilih tombol Start pada tampilan Menu untuk memulai aplikasi, tombol Exit untuk keluar dari aplikasi, dan Help untuk membuka deskripsi halaman. Halaman Main Menu ditampilkan saat user menekan tombol Start dan memberikan pilihan untuk mengakses jenis koleksi atau memulai augmented reality dengan kamera.

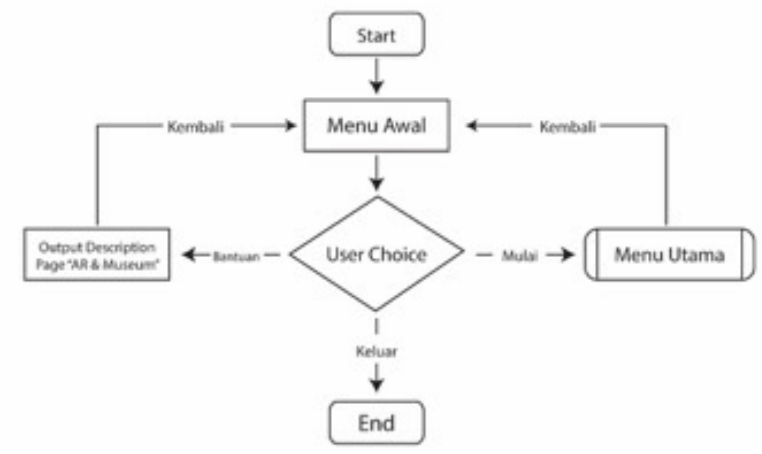

Gambar 3. Diagram alur operasional menu awal

User dapat mengetahui koleksi apa yang telah ditemukan oleh augmented reality dengan memilih tombol koleksi dalam Main Menu, kemudian untuk memulai augmented reality user dapat mengaktifkan kamera dengan memilih tombol camera untuk melakukan scan marker. Objek 3D akan muncul saat kamera mendeteksi adanya marker pada layer mobile.

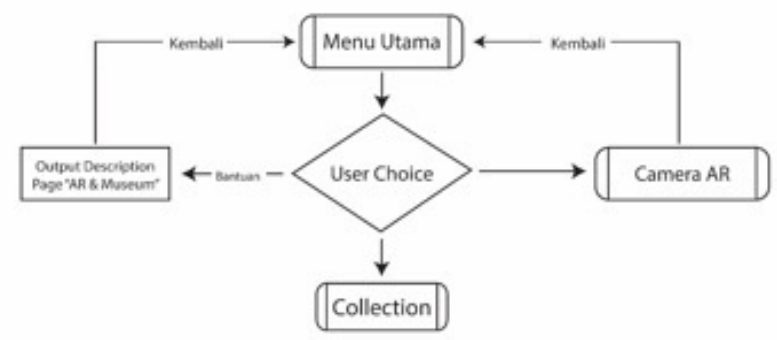

Gambar 4. Diagram alur operasional menu utama

Kamera Augmented reality yang mendeteksi adanya marker akan menampilkan 3D object dari koleksi museum yang dilengkapi dengan fitur zoom in, zoom out, rotate, dan play animation. Ketiga fitur terkecuali play animation dibuat user friendly sehingga dengan tampilan minimalis dan sederhana pun, user dapat menguasai penggunaan fitur tersebut.

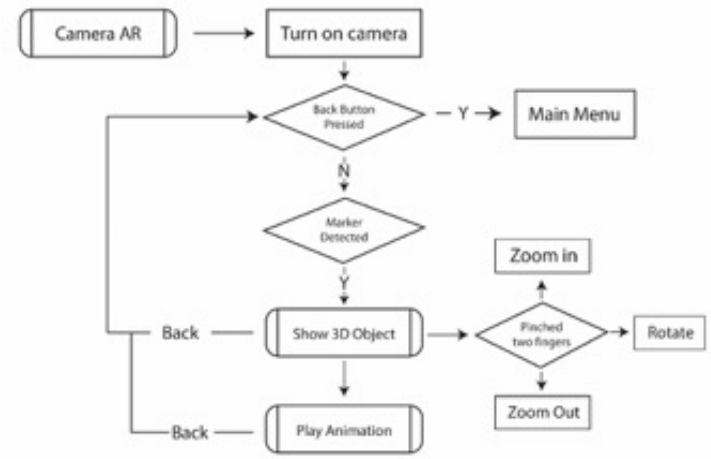

Gambar 5. Diagram alur operasional kamera aplikasi

Desain Layout dan Grafis Antarmuka Media

Aplikasi Augmented reality untuk koleksi Museum Panji Malang ini terdiri dari lima halaman, yaitu: Start Menu (menu awal), Main Menu (menu utama), Help Description (deskripsi bantuan), Collection Page (Halaman koleksi), dan Show 3D Object (tampilan objek 3D). Tampilan menu awal dimulai dengan adanya ilustrasi tentang museum, lalu dilengkapi dengan fitur pemilihan bahasa Indonesia atau English sehingga memudahkan wisatawan lokal maupun mancanegara untuk menggunakan aplikasi ini, dan tombol bantuan untuk menjelaskan mengenai aplikasi ini diletakkan di pojok kanan atas tombol start sehingga memudahkan user untuk menemukannya. 


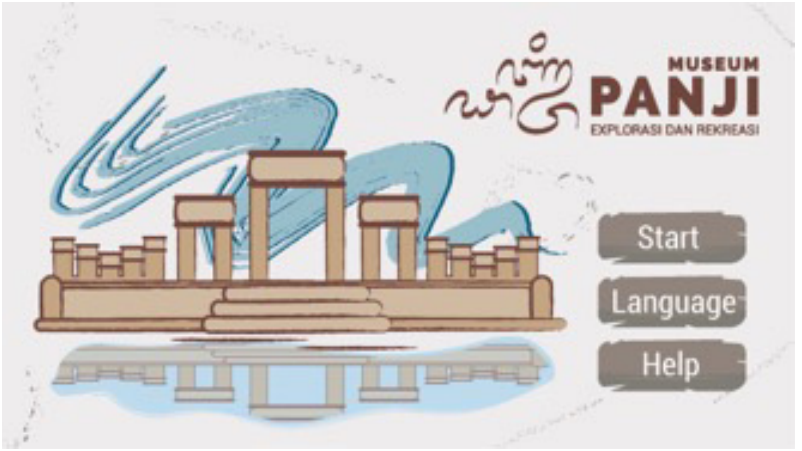

Gambar 6. Desain layout dan grafis antarmuka menu awal aplikasi

Tampilan menu utama ditampilkan dengan adanya ilustrasi museum dengan tombol bantuan, koleksi, dan kamera. Tombol bantuan menu utama diletakkan di samping koleksi, berisi tentang deskripsi halaman dan cara kerja aplikasi. Tombol koleksi untuk mengakses koleksi apa saja yang perlu dan sudah di-scan oleh kamera augmented reality. Tombol kamera untuk melakukan scan marker koleksi.

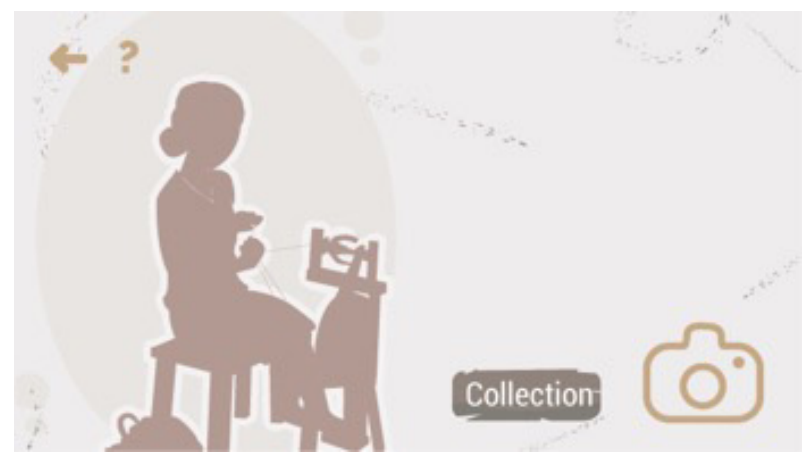

Gambar 7. Desain layout dan grafis antarmuka menu utama aplikasi

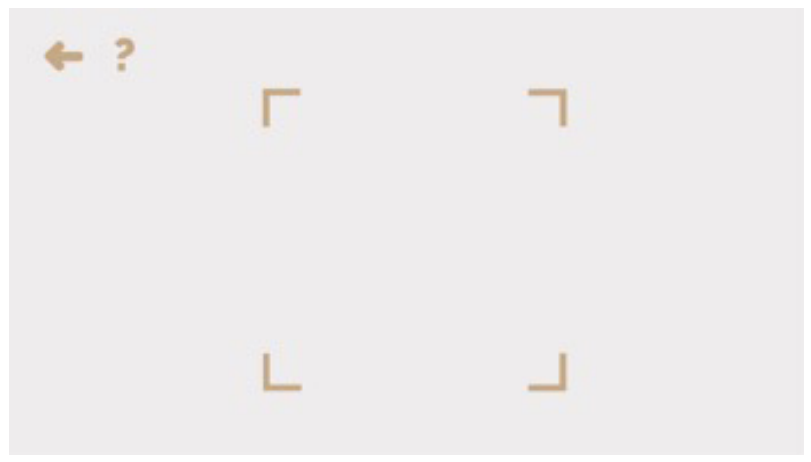

Gambar 8. Desain layout dan grafis antarmuka kamera aplikasi

Tampilan halaman koleksi menampilkan macam-macam icon koleksi dari jenis koleksi museum. Jenis koleksi yang diangkat untuk perancangan adalah jenis etnografi klasik yang terdiri dari beberapa objek. Icon etnografi akan ditampilkan pada bagian kiri dan deskripsi benda saat menekan salah satu icon terletak pada bagian kanan. Apabila belum menemukan atau scan objek tersebut, maka icon masih dalam tampilan hitam putih yang berarti locked.

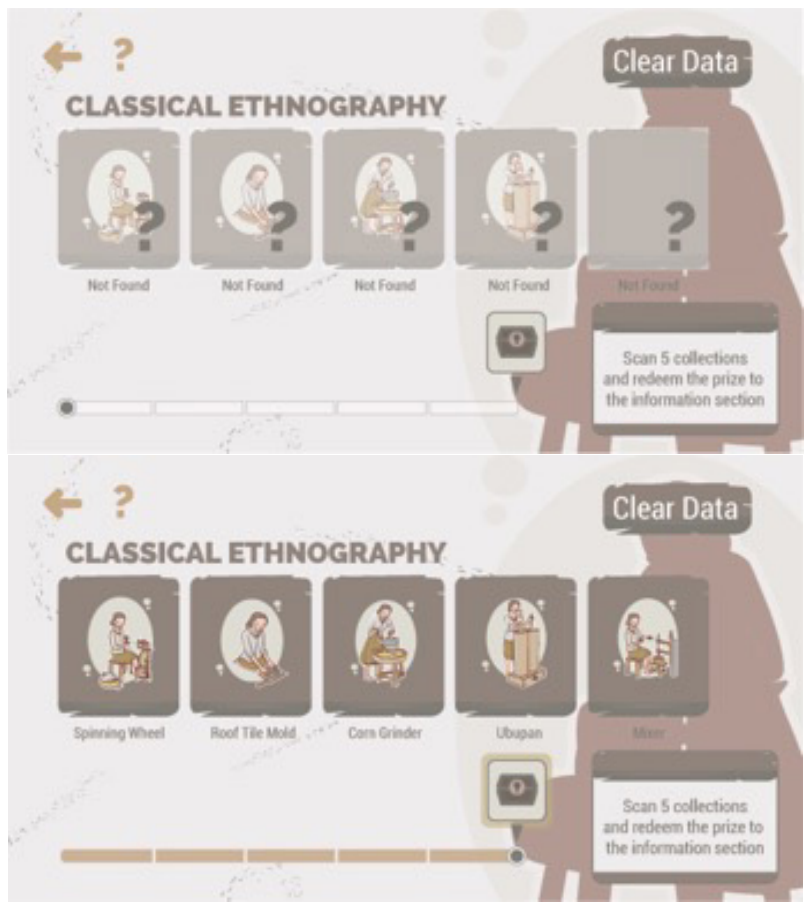

Gambar 9. Layout dan elemen grafis antarmuka koleksi artefak sebelum (atas) dan sesudah (bawah) proses scan kamera

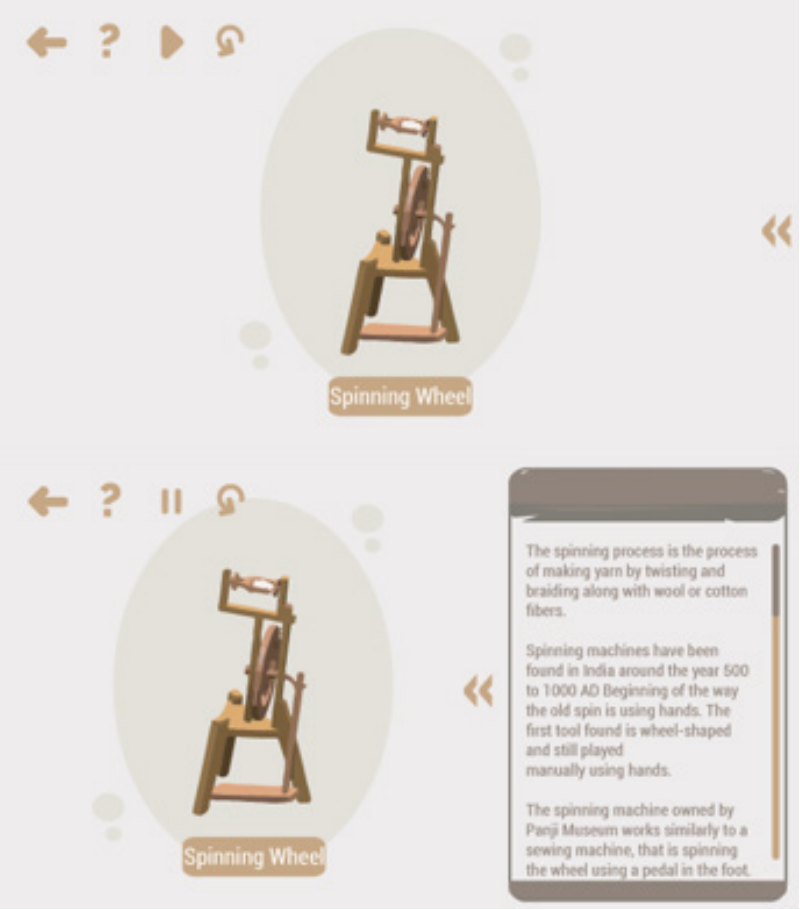

Gambar 10. Desain layout dan grafis antarmuka deskripsi interaktif artefak

\section{Pemodelan 3D Artefak Virtual}

Desain 3D model dari aplikasi akan tampil saat kamera dari perangkat user mendeteksi marker. 3D model ini memiliki fungsi sebagai media bantu pembelajaran yang dapat 
menjelaskan proses kerja dan bentuk koleksi. 3D model akan didesain dengan sederhana dan tetap fungsional yang menjawab tujuan. Gaya desain 3D model akan berunsur kartun dengan texture sederhana dan tepian objek cenderung tidak lancip. Animasi ditambahkan sebagai media bantu penjelas cara kerja koleksi. Animasi dibuat secara sederhana dan mudah dipahami oleh pengguna.

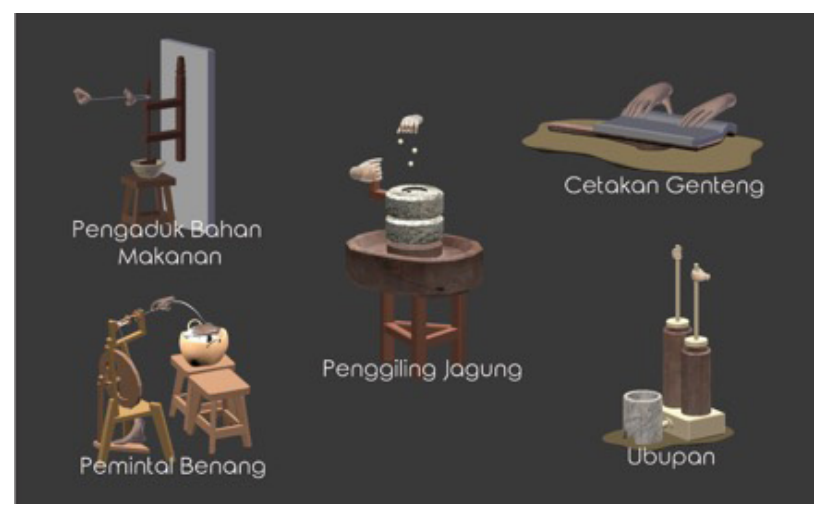

Gambar 11. Tampilan artefak secara virtual melalui pemodelan citra 3D

\section{Desain Layout dan Grafis Caption display}

Caption display sebagai media penghubung antara koleksi dengan media augmented reality. Desain yang dibuat untuk caption display dibuat dengan tidak terlalu rumit dan menggunakan warna kontras yang cerah.

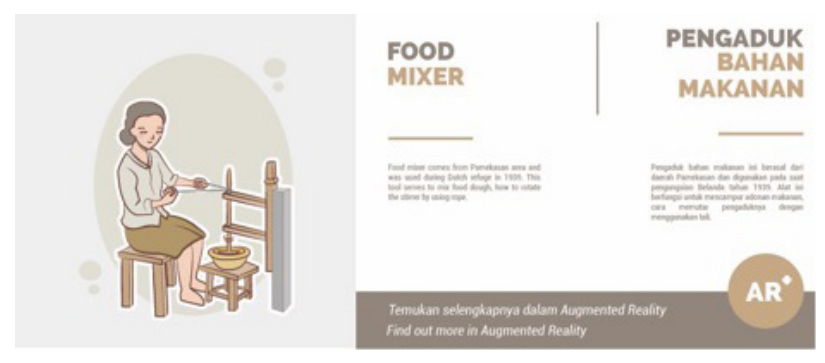

Gambar 12. Contoh layout dan grafis caption display cetak

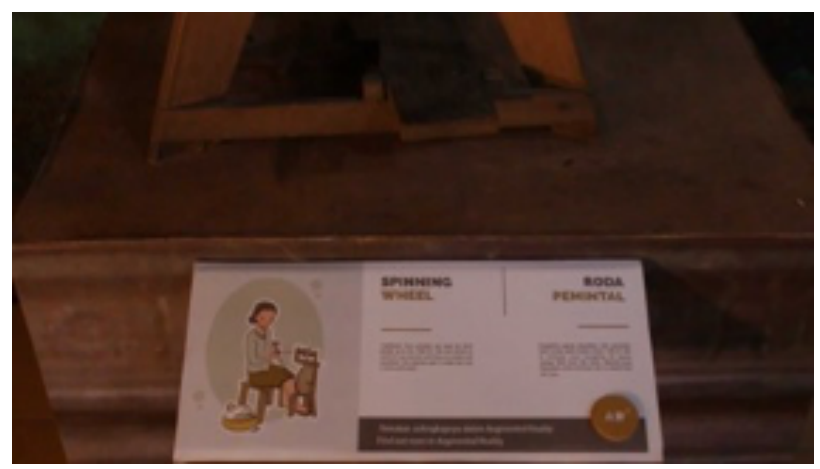

Gambar 13. Penempatan caption display cetak pada artefak

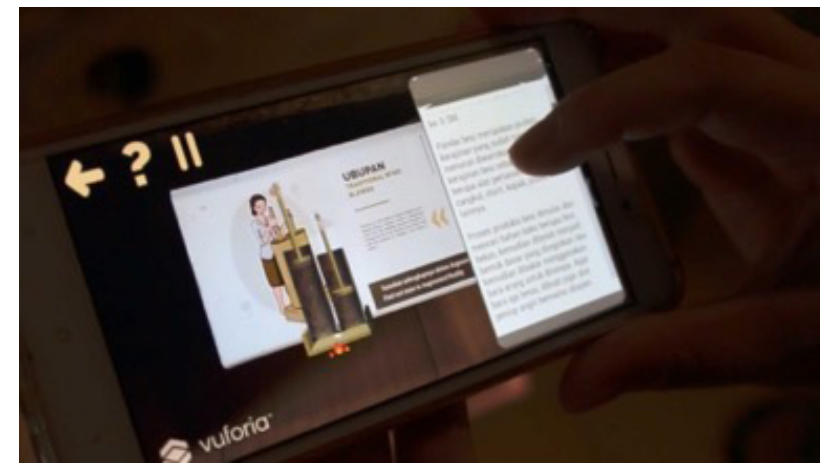

Gambar 14. Aktifasi deskripsi artefak melalui aplikasi

\section{Uji Aplikasi}

Uji aplikasi dilaksanakan dengan tujuan untuk mengamati sejauh mana aplikasi dapat berfungsi sebagaimana tujuan rancangan. Selain itu melalui uji aplikasi juga bermanfaat untuk mendapatkan umpan balik dari pemakai seberapa mudah dan nyaman aplikasi digunakan.

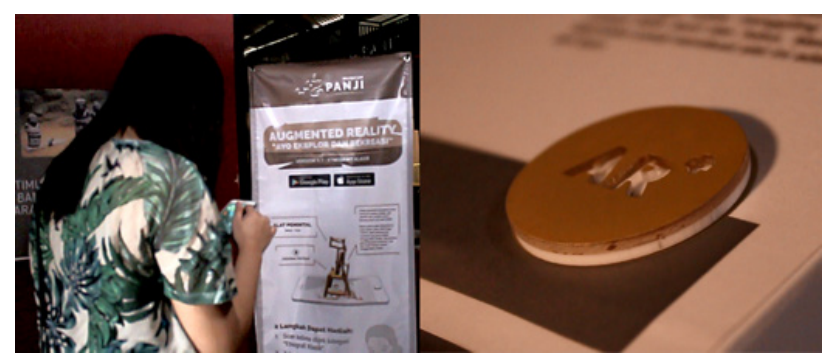

Gambar 15a. Ujicoba Langkah 1 - Menjalankan aplikasi sebagaimana arahan banner

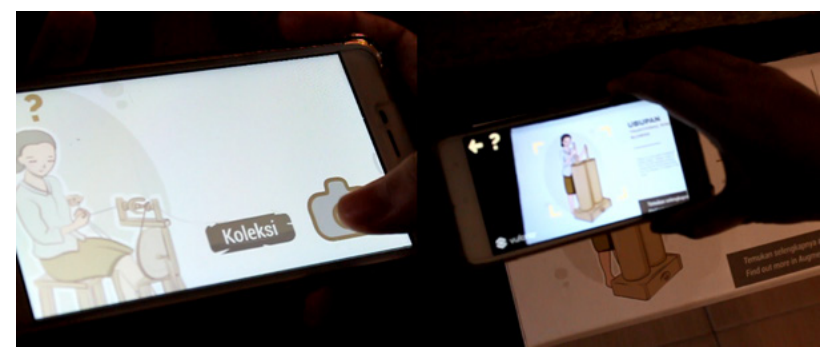

Gambar 15b. Ujicoba Langkah 2 - Mengaktifkan kamera dan arahkan ke marker

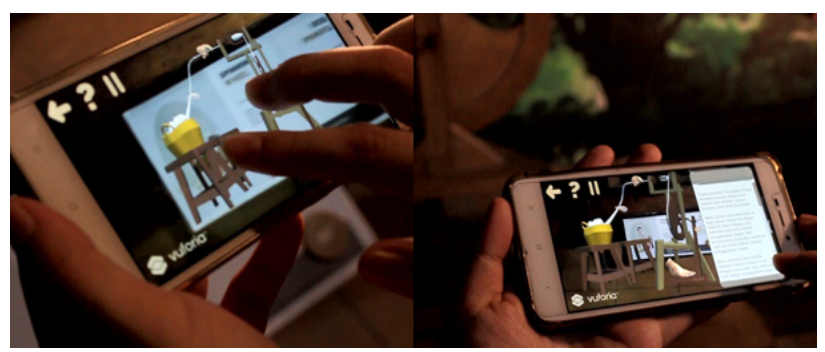

Gambar 15c. Ujicoba Langkah 3 - Interaksi dengan konten 3D dan deskripsi koleksi 


\section{SIMPULAN}

Pada kasus caption artefak koleksi Museum Panji Malang, teknologi augmented reality mampu diterapkan dalam meningkatkan kuantitas dan kualitas caption sebagai media penyampai informasi. Augmented reality dapat menyajikan visualisasi pemodelan 3D dan animasi 3D yang interaktif dan paparan dalam bentuk teks yang lebih terinci daripada caption display. Karakteristik interaktif yang dimiliki teknologi ini juga memungkinkan diterapkannya sistem gamifikasi sebagai bagian dari komunikasi informasi. Hal tersebut memunculkan relevansi antara pengunjung dan informasi yang disajikan, sehingga memungkinkan kedekatan emosional yang dapat membantu transformasi informasi menjadi pengetahuan bagi pengunjung.

Penerapan dari teknologi ini harus disertai dengan penambahan dan penataan elemen caption. Hal tersebut bertujuan untuk menyelaraskan informasi yang divisualkan secara fisik dengan yang secara virtual. Informasi dari kedua wujud visual tersebut seharusnya dapat berdiri sendiri untuk mempertimbangkan kepraktisan, tetapi juga mampu berkaitan untuk memperkaya kuantitas dan kualitas informasi yang disajikan. Perancangan ulang dari caption yang terdapat di Museum Panji dimungkinkan dengan adanya persetujuan dan implementasi dari pihak pengelola museum. Sehingga dapat disimpulkan bahwa aplikasi dari teknologi augmented reality dalam memperkaya kuantitas dan kualitas informasi yang terdapat dalam caption artefak tidak hanya sebatas pada perencanaan strategi komunikasi dan pembuatan konten, tetapi juga harus melibatkan seluruh komponen dari pengelolaan operasional museum.

\section{DAFTAR RUJUKAN}

Akaibara. (2017). Museum Panji yang Bertaraf Internasional Ada di Tumpang. Retrieved December 12, 2017, from https://ngalam.co/2017/04/28/museum-panjibertaraf-internasional-ada-tumpang

Carmigniani, J. and Furht, B. (2011). Augmented Reality: An Overview. Handbook of Augmented Reality. Springer.

Hollerer, T. and Schmalstieg, D. (2016, June 10). Introduction to Augmented reality. Retrieved February 06, 2018, from http://www.informit.com/articles/article. $\operatorname{aspx} ? \mathrm{p}=2516729$

Kenney, K. (2008, November 13). Writing Exhibit Labels Museum Professional Forum, News, Jobs, Articles, Books. Retrieved March 20, 2018, from https://web.archieved.org/ web/20110430212508/ http:/www.museumprofessionals. org/forum/member-articles/2424-writing-exhibit-labels. html

McTavish, L. (2013). Defining the Modern Museum: A Case Study of the Challenges of Exchange. Toronto: University of Toronto Press.
Silvia, R., Oliveira, J. C., \& Giraldi, G. A. (2003). Introduction to Augmented reality. 1-11. Retrieved March 20, 2018, from lncc.br/ jauvane/papers/ RelatorioTecnicoLNCC-2503.pdf. 